\title{
IMPLEMENTASI MANAJEMEN SUMBER DAYA MANUSIA DI MAN YOGYAKARTA III
}

\author{
Hidayatus Sholihah ${ }^{1}$
}

\begin{abstract}
This study is aimed at revealing the functions of human resource management in MAN Yogyakarta III (State Islamic Senior High School) that includes human resource planning, recruitment, selection and placement, training and development, performance appraisal, compensation, health program, teacher and employee relation and the effectiveness of human resource management.

This study is a qualitative research. The subjects of this study are the principal, teachers, employees and students of MAN Yogyakarta III. The data were collected through participant observation, semi-structured interview and documentation. The technique employed to measure the data validity was triangulation. The research instrument was the researcher herself. The data were analyzed using interactive model consisting of three phases: data reduction, data display, and verification.

The findings show that MAN Yogyakarta III (1) arranges human resource planning based on the vision, however, it is not effective because madrasah has no right to plan; (2) recruits competent teachers and employees effectively through news paper; (3) sets four types of effective selection: administration selection, academic selection, interview and micro teaching and positions the teachers and employees based on their academic qualification and competences; (4) implements effective training and development programs in accordance with the teachers' and employees' needs such as sharing ideas and knowledge, comparative study, internal presentation, evaluation and coordination; (5) appraises performance by checking the administration of teaching and supervision but the implementation of performance appraisal is not effective. (6) gives the effective compensation for the teachers and employees in accordance with their status; (7) undertakes effective health programs by creating clean and healthy school environment; (9) organizes some programs to establish effective relationship between the teachers and employees.
\end{abstract}

Keywords: Human Resources, micro teaching, supervision

Dosen Program Studi Pendidikan Agama Islam (PAI) Jurusan Tarbiyah Fakultas Agama Islam (FAI) Universitas Islam Sultan Agung (UNISSULA) Semarang 


\section{ABSTRAK}

Penelitian ini bertujuan untuk mengungkapkan fungsi-fungsi operasional manajemen sumber daya manusia di MAN Yogyakarta III (Madrasah Aliyah Negeri) yang terdiri dari: perencanaan sumber daya manusia, proses rekrutmen, seleksi dan penempatan, training dan pengembangan, penilaian kinerja, kompensasi, program kesehatan, hubungan guru dan pegawai serta keefektifan manajemen sumber daya manusia di MAN Yogyakarta III.

Penelitian ini merupakan penelitian kualitatif. Subjek dalam penelitian ini ialah kepala sekolah, para guru dan pegawai MAN Yogyakarta III. Data dikumpulkan melalui observasi partisipan, wawancara bebas terpimpin dan dokumentasi. Tekhnik yang digunakan untuk mengukur validitas data ialah triangulasi. Peneliti berperan sebagai instrumen penelitian. Analisis data dilaksanakan sejak data terkumpul, dengan menggunakan model interaktif yang terdiri dari tiga bagian: 1 . mereduksi data; 2 . menyajikan data; 3 . verifikasi.

Hasil penelitian menunjukkan bahwa MAN Yogyakarta III (1) menyusun perencanaan SDM yang mengacu pada visi madrasah tetapi hal ini tidak efektif karena madrasah tidak memiliki hak untuk merencanakan; (2) merekrut guru dan pegawai yang kompeten secara efektif melalui surat kabar; (3) menetapkan empat jenis seleksi yang efektif yaitu: seleksi administrasi, seleksi akademik, wawancara dan micro teaching dan menempatkan guru dan pegawai berdasarkan pada kualifikasi akademik dan kompetensi yang mereka miliki; (4) menyelenggarakan program training dan pengembangan secara efektif yang disesuaikan dengan kebutuhan guru dan pegawai seperti curah ide dan wawasan, study banding, presentasi internal dan evaluasi dan koordinasi; (5). menilai kinerja dengan cara mengecek kelengkapan administrasi mengajar guru dan supervisi tetapi pelaksanaan penilaian kinerja belum efektif; (6) memberikan kompensasi secara efektif kepada guru dan pegawai berdasarkan status mereka; 7) menyelenggarakan program kesehatan yang efektif dengan menciptakan lingkungan sekolah yang bersih dan sehat; 9) menyusun program-program untuk menjalin hubungan antara guru dan pegawai secara efektif.

Kata kunci: Sumber Daya Manusia, micro teaching, supervisi

\section{A. PENDAHULUAN}

Sumber daya manusia, fasilitas dan pendanaan yang memadai dalam lembaga pendidikan merupakan faktor-faktor penting yang turut mempengaruhi kualitas pendidikan (Sanusi Uwes, 1999: v). Menurut Eaton (Budi Soepetidjo, 2005) satu-satunya cara untuk memenangkan kompetisi ialah dengan sumber daya manusia. Dari pendapat tersebut dapat diketahui bahwa sumber daya manusia merupakan faktor terpenting di antara faktorfaktor lain yang telah disebutkan di atas. 
Keterpurukan pendidikan di Indonesia termasuk Madrasah Aliyah dapat terlihat dari hasil evaluasi ujian akhir yang masih di bawah standar jika dibandingkan dengan negara-negara lain. Hal tersebut juga sangat dipengaruhi oleh faktor terbatasnya sumber daya manusia yang memadai untuk pencapaian pendidikan yang berkualitas (Faisal Jalal \& Dedi Supriyadi, 2001: 59). Rendahnya kualitas sumber daya manusia tersebut merupakan dampak dari minimnya dana pendidikan (Naning Mardiyah, 2003: 6).

Madrasah Aliyah sebagai institusi pendidikan formal menjadi salah satu lembaga penting yang menghadirkan pemberdayaan sumber daya manusia secara menyeluruh yang memadukan antara pengetahuan agama dengan pengetahuan umum (Malik Fadjar, 1998: 7). Madrasah Aliyah sesungguhnya mempunyai peluang yang produktif pada situasi krisis identitas pendidikan nasional yang berbasis pengembangan science dan moral. Model pendidikan yang dikembangkan oleh madrasah mencoba mengadopsi materi umum yang dikembangkan oleh sekolah umum dan mengakomodir bahan-bahan keagamaan yang diajarkan dalam dunia pesantren. Madrasah Aliyah sebagai lembaga pendidikan yang mempunyai visi lebih komprehensif dalam situasi yang demikian itu sebenarnya mempunyai keuntungan yang berbeda dibandingkan dengan sekolah umum, akan tetapi kenyataannya lebih sering ditemukan bahwa baik visi misi maupun penguatan sumber daya manusia dalam lembaga madrasah juga belum sepenuhnya optimal (Malik Fadjar, 1998: 7).

Perkembangan ekonomi dan kecanggihan teknologi menuntut setiap anggota masyarakat untuk berkompetisi dalam dunia kerja (Suyanto dan MS Abas, 2001: 93). SDM MAN Yogyakarta III secara tidak langsung kemudian terbawa untuk mempersiapkan diri dan anak didik dalam kompetisi global dengan meningkatkan kompetensi diri agar dapat memberikan modal pengetahuan dan skill serta basis moralitas bagi anak didik. MAN model diantaranya merupakan gagasan dalam mempersiapkan sumber daya manusia dalam dunia kerja. Namun demikian, untuk mendapatkan out put yang benarbenar tangguh dan siap berkompetisi tersebut banyak dibutuhkan persiapan dan pembenahan dalam lingkup internal madrasah sendiri (Observasi tanggal 20 Desember 2007).

Dari deskripsi tentang kelemahan yang selama ini ada dalam kelembagaan madrasah, maka dalam penelitian di MAN Yogyakarta III ini peneliti mencoba memahami dan mencari pemecahan masalah dalam upaya membangun kembali kelemahan-kelemahan manajerial di lembaga madrasah, yakni sumber daya manusia sehingga madrasah tidak lagi identik dengan lembaga pendidikan yang menyiapkan sumber daya manusia yang kompeten dalam bidang agama semata, namun juga dalam keilmuan komprehensif tanpa dikotomi antara ilmu agama dan umum. 
MAN Yogyakarta III merupakan MAN model untuk Daerah Istimewa Yogyakarta (Profil MAN Yogyakarta III tahun 2007). Dipilihnya MAN Yogyakarta III sebagai objek dalam penelitian ini, karena MAN Yogyakarta III mampu mengelola input yang kurang baik menjadi output yang baik. Kesuksesan madrasah sebagai keunikan dalam penelitian ini tentu tidak terlepas dari terwujudnya manajemen SDM yang terselenggara di dalamnya, karena kualitas out put pendidikan sangat dipengaruhi oleh bagusnya sumber daya manusia yang mengelola.

Penelitian ini bertujuan untuk mengetahui bagaimana pelaksanaan manajemen sumber daya manusia di MAN Yogyakarta III yang meliputi perencanaan, proses rekrutmen, seleksi, penempatan, training dan pengembangan, penilaian kinerja, kompensasi, kesehatan SDM, hubungan SDM dan untuk mengetahui seberapa efektif pelaksanaan manajemen sumber daya manusia yang ada di MAN Yogyakarta III.

Teori-teori yang berhubungan erat dengan objek yang diteliti sebagai interpretasi atas fenomena-fenomena yang terjadi selama penelitian ialah teori tentang keefektifan dan manajemen SDM.

Youngblood (1987: 30) menyatakan bahwa "the effectiveness can be determined by comparing the cost and benefit. The more benefit at less cost, the greater the effectiveness". Keefektifan dapat ditentukan dengan membandingkan antara biaya dan keuntungan. Semakin besar keuntungan dengan biaya minimal berarti semakin efektif. . Dalam tesis ini keefektifan SDM dapat diukur atau ditentukan dengan membandingkan hasil nyata dengan hasil ideal, proses nyata dengan proses yang direncanakan.

Manajemen sumber daya manusia mempunyai beragam definisi berdasarkan pendapat dari berbagai tokoh. Namun demikian pada dasarnya berbagai pendapat tersebut memiliki inti yang sama. Beberapa tokoh tersebut diantaranya ialah Monday, Noe dan Premeaux (1999: 4) yang berpendapat bahwa "human resources management is the utilization of human resources to achieve organizational objectives". Manajemen sumber daya manusia ialah pemanfaatan sumber daya manusia untuk meraih tujuan-tujuan organisasi.

Menurut DeCenzo (1999: 9), ada empat aktivitas utama dalam manajemen sumber daya manusia yaitu;

a. Staffing yang meliputi perencanaan sumber daya manusia, perekrutan, seleksi dan penempatan.

b. Training and Development yang meliputi orientasi, pelatihan dan pengembangan karyawan dan pengembangan karier.

c. Motivation yang termasuk didalamnya ialah penilaian kinerja, kompensasi, insentif dan bonus karyawan. 
d. Maintenance yaitu untuk mempertahankan komitmen karyawan yang meliputi jaminan keamanan dan kesehatan, komunikasi dan hubungan pegawai.

\section{B. METODE PENELITIAN}

Pendekatan yang digunakan dalam penelitian ini adalah pendekatan kualitatif yang didukung oleh data kuantitatif. Dalam penelitian ini, peneliti tidak hanya sekedar mendeskripsikan tentang implementasi managemen SDM di MAYOGA, namun juga melakukan analisa untuk mengukur keefektifan managemen SDMnya, dengan cara membandingkan antara proses nyata dengan proses yang direncanakan. Penelitian ini dilakukan dalam situasi yang wajar untuk melihat secara natural di lapangan dan lebih mementingkan proses dari pada hasil. Metode yang digunakan dalam penelitian ini adalah metode deskriptif analitis kritis yang berusaha untuk melihat dan memaparkan fakta tentang manajemen sumber daya manusia di MAN Yogyakarta III kemudian dikaitkan dan diverifikasi serta dianalisis secara kritis dengan menggunakan teori-teori MSDM. Untuk memperoleh data yang diperlukan dalam penelitian ini digunakan metode sebagai berikut:

1. Observasi Partisipan (Participant Observation)

2. Wawancara Bebas Terpimpin (Semi-structured interview)

3. Analisis Dokumen

\section{HASIL PENELITIAN DAN PEMBAHASAN}

1. Perencanaan Sumber Daya Manusia

Menurut kepala urusan bidang kurikulum, perencanaan SDM di MAN Yogyakarta III terkait langsung dengan pemerintah karena madrasah ini merupakan sekolah negeri. Ketika pemerintah belum mampu memenuhi jumlah guru dan pegawai PNS yang ideal maka kekurangan guru dan pegawai tersebut dipenuhi secara mandiri oleh madrasah (wawancara tanggal 22 Maret 2007). Dalam hal ini MAN Yogyakarta III melakukan perencanaan untuk meyakinkan bahwa kebutuhan sumber daya manusia mereka terpenuhi. Perencanaan ini disusun berdasarkan visi madrasah yaitu "terwujudnya siswa yang unggul, terampil, dan berkepribadian matang" (profil MAN Yogyakarta III tahun 2007) dan dilakukan dengan mengidentifikasi kebutuhan akan sumber daya manusia, memprediksi SDM yang tersedia dan menentukan tambahan atau penggantian posisi apa yang dibutuhkan untuk menguatkan kualitas dan kuantitas staff yang diperlukan guna meraih misi madrasah. Dari perencanaan SDM yang telah dilakukan oleh MAN Yogyakarta III maka tersedianya kebutuhan akan SDM dapat diidentifikasi sehingga tujuan madrasah 
dapat diraih. Meskipun demikian, MAN Yogyakarta III tidak memiliki hak penuh untuk melakukan perencanaan SDM sehingga perencanaan tersebut tidak efektif.

2. Proses Rekrutmen

Perekrutan guru maupun pegawai madrasah dilakukan langsung oleh Departemen Agama pusat melalui seleksi PNS. Namun demikian, ada beberapa guru maupun pegawai tidak tetap yang direkrut secara mandiri oleh madrasah berdasarkan kebutuhan madrasah sendiri. Dalam sebuah wawancara, wakil kepala madrasah menjelaskan tentang bagaimana proses rekrutmen guru dan pegawai tidak tetap yang diselenggarakan oleh madrasah. Kepala sekolah mengatakan "Rekrutmen yang telah kami selenggarakan ditujukan untuk dapat menjaring para lulusan perguruan tinggi yang berkualitas unggul" ( wawancara tanggal 21 Maret 2007).

Agar tujuan untuk mendapatkan para calon guru dan pegawai yang terbaik maka madrasah melakukan sosialisasi secara luas tentang kegiatan rekrutmen tersebut. Sosialisasi ini dilakukan melalui iklan surat. Rekrutmen SDM di MAN Yogyakarta III telah terlaksana secara efektif karena dalam pelaksanaannya, madrasah mampu merekrut calon guru yang sangat banyak yaitu dengan perbandingan $1: 50$ antara jumlah pelamar dengan jumlah guru yang dibutuhkan sehingga madrasah memiliki peluang yang sangat besar untuk memilih guru berkualitas unggul dan berkompetensi tinggi relevan dengan kebutuhan madrasah.

3. Proses Seleksi dan penempatan

Langkah-langkah yang ditempuh oleh madrasah untuk menyeleksi guru dan pegawai baru sudah efektif karena MAN Yogyakarta III telah mengadakan proses seleksi dengan sangat ketat untuk memperoleh guru yang berkualitas unggul. Hal ini sebagaimana yang disampaikan oleh wakil kepala madrasah "Kami melakukan proses seleksi guru dengan sangat ketat bahkan melebihi seleksi guru PNS" (wawancara tanggal 21 Maret 2007). Seleksi penerimaan guru diadakan untuk memenuhi kebutuhan madrasah terhadap adanya guru tambahan baru. Adapun proses seleksi yang dilakukan untuk mendapatkan guru yang berkualitas dan memenuhi kebutuhan madrasah tersebut ialah dengan mengadakan seleksi administrasi. Bagi pelamar yang lolos seleksi administrasi akan mendapat panggilan untuk mengikuti test tertulis yang terdiri dari test potensi akademik, test pedagogik, test psikologis atau kepribadian atau psycho-test. Setelah itu, madrasah mengadakan test wawancara untuk menilai hal-hal yang tidak tercakup dalam ujian tertulis dan test micro 
teaching. Test ini diformat seperti mengajar yang sesungguhnya yaitu para calon guru baru di minta untuk mengajar langsung di depan kelas atau di hadapan para siswa. Setelah proses seleksi berakhir maka guru atau pegawai baru ditempatkan sesuai dengan kualifikasi dan kompetensi yang mereka miliki.

4. Training dan Pengembangan SDM

Sebagai MAN Model maka MAN Yogyakarta III harus memiliki SDM yang unggul. Oleh karena itu MAN Yogyakarta III melakukan usaha - usaha penguatan SDM yang berupa training dan pengembangan secara kontinyu dan konsisten Kepala urusan pembinaan profesi beserta timnya menyusun program kerja dengan tujuan untuk mengembangkan SDM madrasah yang meliputi 2 program yaitu program fisik dan non fisik.

Adapun program fisik dan non fisik dalam pengembangan SDM (wawancara tanggal 27 Maret 2007) ialah sebagai berikut:

Program fisik terdiri dari:

a. Penempelan teks kompetensi guru dan kode etik guru di dinding

b. Pengadaan format-format pembelajaran dan supervisi kunjungan kelas

c. Menfasilitasi program rumpun mata pelajaran bekerja sama dengan urusan sarana dan prasarana.

d. Menata ruang guru, ruang pertemuan guru dan pegawai, lingkungan madrasah senyaman dan selengkap mungkin dengan bekerjasama dengan urusan sarana prasarana.

Sedangkan program non fisik meliputi :

a. Curah ide dan wawasan

b. Belanja ilmu

c. Presentasi internal

d. Evaluasi dan koordinasi

Dari training yang telah diselenggarakan dapat diketahui bahwa madrasah telah melakukan berbagai langkah untuk memaksimalkan penyelenggaraan training dan pengembangan yakni dengan mengidentifikasi kebutuhan, menentukan sasaran dan menetapkan isi progam. Dalam hal ini, identifikasi kebutuhan yang telah dilakukan ialah dengan memanfaatkan penilaian kinerja guru dan pegawai serta meminta masukan langsung dari para guru. Berbagai training dan pengembangan yang diselenggarakan secara terprogram dan terorganisir oleh madrasah serta banyaknya training yang diselenggarakan oleh pihak luar madrasah yang diikuti oleh para guru dan pegawai menunjukkan bahwa MAN Yogyakarta III sangat aktif dalam upaya mengembangkan para guru dan pegawainya untuk 
senantiasa berbenah diri, mengaktualisasikan diri dan meningkatkan kualitas diri. Nampaknya usaha ini tidak sia-sia karena terbukti training dan pengembangan tersebut dapat meningkatkan motivasi serta memperbaiki kinerja guru dan pegawai madrasah. Dengan meningkatnya kompetensi guru maka berdampak pada keberhasilan para guru mengolah in put yang tidak baik menjadi out put yang baik. Dengan demikian fungsi training dan pengembangan di MAN Yogyakarta III telah berjalan dengan efektif.

5. Penilaian Kinerja Guru dan Karyawan.

Menurut kepala urusan pembinaan profesi, Penilaian kinerja guru di MAN Yogyakarta III dilakukan dengan cara sebagai berikut :

a. Mengecek dan menilaikelengkapan administrasiyang telah disusun oleh guru yang meliputi; Program Tahunan (PROTA), Program Semester (PROSEM), Silabus dan Rencana Program Pengajaran (RPP). Di samping itu juga mengecek perangkat mengajar guru di kelas seperti buku paket yang menjadi pegangan guru, lembar kerja siswa (LKS), media atau alat peraga pembelajaran, lembar penilaian proses dan hasil pembelajaran, kalender akademik dan presensi siswa.

b. Melakukan supervisi di kelas. Supervisi di kelas yang pada umumnya dilakukan langsung oleh kepala madrasah namun tidak demikian di MAN Yogyakarta III. Supervisi kelas yang dilakukan di madrasah ini didelegasikan oleh kepala madrasah kepada kepala urusan pembinaan profesi dan para stafnya. Kepala pembinaan profesi sekaligus guru pelajaran Biologi mengatakan "Tidak mungkin saya sebagai guru biologi harus mensupervisi seluruh guru bidang study yang berbeda dengan saya, bagaimana nanti hasilnya".

Supervisi kelas dilaksanakan pada setiap pertengahan semester atau setahun dua kali. Hasil penelitian di lapangan menunjukkan bahwa beberapa guru merasakan penilaian kinerja sebagai "momok" atau pengalaman yang menyakitkan. Di samping itu, para guru senior yang dilimpahi wewenang untuk melaksanakan penilaian kinerja terhadap guru yunior belum terbiasa untuk menyusun kelengkapan administrasi mengajar dan hanya menyusunnya jika mereka ingin mengajukan pangkat atau golongan. Dengan demikian pelaksanaan penilaian kinerja guru belum efektif.

6. Kompensasi.

Sebagaimana lembaga pemerintah pada umumnya maka sistem gaji madrasah sama dengan institusi lain yang berada di bawah departemen pusat. 
a. Kompensasi material

Kompensasi yang berupa materi yang diberikan oleh MAN Yogyakarta III kepada para guru dan pegawainya didasarkan pada golongan yang mereka miliki. Berdasarkan wawancara dengan kepala madrasah, ada empat golongan guru dan pegawai yaitu:

1) Guru atau pegawai yang berstatus PNS.

2) Guru bantu pusat.

3) Pegawai tetap madrasah / Non PNS.

4) Guru Tidak Tetap (GTT) / Pegawai Tidak Tetap (PTT).

b. Kompensasi non material

Jika ada guru atau pegawai yang melakukan kinerjanya dengan bagus dan dapat meraih berprestasi, Kepala Madrasah mengatakan,

Saya akan menemui guru tersebut secara personal untuk memberikan materi sekedarnya sebagai rasa terima kasih, memberi ucapan selamat secara lisan serta memberikan surat ucapan selamat dari madrasah atas prestasi yang diraih (Wawancara tanggal 12 April 2007).

Selain itu, semua guru atau pegawai maupun siswa yang berprestasi akan diumumkan lewat upacara sekolah pada hari Senin pagi maupun lewat pertemuan rutin guru dan pegawai. Dengan demikian kompensasi yang diterima oleh para guru maupun pegawai di MAN Yogyakarta III tidak saja berupa materi tetapi juga non materi.

Selain kompensasi materiil, madrasah juga memberikan kompensasi non materi. Kompensasi non materi diberikan dalam bentuk ucapan selamat serta penghargaan dengan mengumumkan prestasi kinerja yang telah diraih oleh guru atau pegawai dalam beberapa forum. Pemberian kompensasi non materi ini dapat menjadi pelengkap atau penyempurna dari kompensasi materi yang mampu diberikan oleh madrasah kepada para guru dan pegawainya. Dengan demikian, madrasah memberikan imbalan kepada para guru dan pegawainya baik dalam bentuk materi maupun non materi sehingga tujuan sistem kompensasi dapat tercapai dan kompensasi SDM di MAN Yogyakarta III sudah efektif.

7. Kesehatan SDM

a. Kesehatan fisik

Kualitas kesehatan dan lingkungan madrasah yang sehat dan prima adalah salah satu faktor yang memiliki andil besar dalam peningkatan kualitas pendidikan di madrasah. Menurut Kepala 
UKS bahwa "pelaksanaan program kesehatan fisik di madrasah ditangani oleh tim secara terprogram dan profesional" (Wawancara tanggal 9 April 2007).

b. Kesehatan Mental

Usaha kesehatan mental bagi para guru dan pegawai di MAN Yogyakarta III dilakukan dengan mengadakan pengajian rutin keluarga besar MAN Yogyakarta III setiap dua bulan sekali. Dengan mengundang ustadz dari luar untuk mengisi siraman rohani dengan tema yang disesuaikan dengan kebutuhan atau kondisi para guru maupun pegawai. Di samping itu Kepala Madrasah mengatakan pada saat wawancara 17 April 2007 bahwa "ketika guru merasa jenuh dan stress maka kami datangkan para ahli psikologi untuk membangkitkan motivasi mereka lagi”.

Tujuan madrasah untuk mempertahankan dan meningkatkan kesehatan para warganya sudah tercapai. Hal tersebut dapat kita lihat dari meningkatnya kemampuan kerja guru dan karyawan. Dengan demikian, usaha untuk menjaga kesehatan di MAN Yogyakarta III sudah efektif.

8. Hubungan Guru dan Pegawai

MAN Yogyakarta III senantiasa menjalin keakraban dan menggalang kerjasama di antara keluarga besar madrasah dan masyarakat sekitar. Untuk tercapainya hubungan yang harmonis tersebut, maka dibentuklah bidang Humas di bawah koordinasi kepala urusan bidang Humas dalam struktur manajemen MAN Yogyakarta III yang berada di bawah pimpinan langsung kepala madrasah. Kepala Humas Madrasah, Nur Syamsudin, menyatakan bahwa Di samping untuk menjalin hubungan baik antara guru dan pegawai, Humas juga bertugas untuk menyampaikan informasi tentang keberhasilan madrasah, keunggulannya dibanding lembaga pendidikan lain yang setingkat (Wawancara tanggal 12 April 2007).

Berikut ini adalah berbagai program kegiatan yang diselenggarakan oleh Humas pada tahun 2006/2007. Seluruh kegiatan tersebut bertujuan untuk menjalin hubungan keakraban di antara sesama warga MAN Yogyakarta III maupun dengan masyarakat sekitar, yaitu:

a. Optimalisasi pemanfaatan web site.

b. Optimalisasi interaktif school.

c. Pengajian rutin keluarga besar MAN Yogyakarta III.

d. Mengadakan MAYOGA ties of friendship

e. Bakti sosial.

f. Penyembelihan hewan qurban dan bakti masyarakat. 
g. Merekrut sponsor.

h. Kerjasama dengan media cetak dan elektronik (TV dan radio).

i. Optimalisasi penggunaan radio siaran.

j. Optimalisasi kerja sama dengan pondok al-Ikhsan.

k. Mensosialisasikan program madrasah.

1. Membentuk organisasi alumni.

m. Pertemuan rutin dengan orang tua atau wali siswa.

n. Penerimaan tamu madrasah.

o. Menyelenggarakan Sekolah Kerja Nyata

(Dokumentasi MAN Yogyakarta III).

MAN Yogyakarta III telah menyusun dan menyelenggarakan berbagai program untuk menjalin komunikasi serta kerjasama antara seluruh warga madrasah seperti kegiatan pengajian rutin keluarga besar MAYOGA, mengadakan MAYOGA ties of friendship, bakti sosial, membentuk organisasi alumni, pertemuan rutin dengan orang tua atau wali siswa, dsb. Program-program tersebut dapat terlaksana secara rutin. Dengan terselenggaranya berbagai program kegiatan di atas maka tujuan madrasah untuk menjalin hubungan SDM yang harmonis dapat tercapai. Dengan demikian hubungan SDM di MAN Yogyakarta III sudah efektif.

\section{KESIMPULAN}

Berdasarkan pembahasan yang telah dilakukan di atas maka dapat dirumuskan pokok-pokok kesimpulan sebagai berikut:

1. Perencanaan SDM sudah mengacu pada visi madrasah tetapi madrasah tidak memiliki hak penuh untuk melakukan perencanaan SDM sehingga perencanaan SDM tidak efektif.

2. Rekrutmen guru dan pegawai yang kompeten sudah efektif, yaitu disosialisasikan melalui media masa.

3. Proses seleksi guru dan pegawai dilakukan dengan sangat ketat untuk mendapatkan SDM yang kompeten. Guru / pegawai tersebut kemudian ditempatkan sesuai dengan kompetensi mereka. Dengan demikian seleksi dan penempatan SDM sudah efektif

4. Pelatihan dan pengembangan SDM sudah efektif karena telah terprogram dan terlaksana secara rutin dan berkesinambungan sehingga motivasi dan kinerja guru / pegawai meningkat dan berhasil mengolah input yang tidak baik menjadi output yang baik.

5. Penilaian kinerja guru yang dilakukan dengan mengecek administrasi guru dan supervisi kelas tidak efektif karena dalam pelaksanaannya beberapa guru belum terbiasa menyusun perangkat mengajar dan supervisi masih menjadi "momok" bagi mayoritas guru. 
6. Kompensasi yang diberikan sudah efektif karena sesuai dengan status guru atau pegawai baik dalam bentuk materi dan non materi sehingga tujuan kompensasi untuk menghargai prestasi kerja dapat tercapai.

7. Pelaksanaan program kesehatan sudah efektif karena ditangani oleh tim secara terprogram dan profesional sehingga kesehatan dan kemampuan bekerja guru dan pegawai dapat meningkat.

8. Berbagai program yang telah disusun dan dilaksanakan untuk menjalin hubungan SDM sudah efektif sehingga kerjasama antara guru dan pegawai dapat berjalan dengan baik.

\section{DAFTAR PUSTAKA}

Amstrong, M. (2003). Strategic resource management: a guide to action. Jakarta: Gramedia.

Anthony W. P., \& Perrewe P. L. (2002). Human resource management: A strategic approach $\left(4^{\text {th }}\right.$ ed). Ohio, South Western: Thomson Learning.

Black, J.A., \& Champion, D. J. (1976). Methods and issues in social research. New York: John Wiley Sons. Inc.

Boundreau, M. (1997). Human resource management ( $8^{\text {th }}$ ed.). California : Times Mirror Inc.

Budi Sopetjipto (4 April 2005). Membangun komitmen SDM. Diambil pada tanggal 17 Maret 2007, dari http://www.hri.or.id /urunrembug 001. $\underline{\mathrm{htm}}$

Chapman. A. (12 Maret 2007). Performance appraisal. Di ambil pada tanggal 1 Juni 2007, dari http://www.businessballs.com/performance appraisals. htm

Danzin, N.K., \& Lincoln, Y.S. (Ed). (1994). Handbook of qualitative research. California: Sage Publication, Inc.

DeCenzo, D.A., \& Robbins, S.P. (1999). Human resource management $\left(6^{\text {th }}\right.$ ed.). New York: John Wiley\& Sons Inc.

DEPAG RI (1998). Manajemen madrasah aliyah. Jakarta: Direktorat Jenderal Pembinaan Kelembagaan Agama Islam.

Dessler, G. (2005). Human resource management ( $10^{\text {th }}$ ed). New Jersey: Pearson Education Inc .

Faisal Jalal \& Dedi Supriyadi ( 2001). Reformasi pendidikan dalam konteks otonomi daerah. Yogyakarta: Adicita. 
Hani Handoko (2001). Manajemen edisi II . Yogyakarta: Penerbit BPFE.

Heidjrachman \& Suad Husnan (1990). Manajemen personalia edisi 4, Yogyakarta: BPFE.

James, Stoner, A.F., Edward, F.R., et al. (1996). Manajemen (Terjemahan Sindoro). Jakarta: PT Prenhallindo.

Lammers, T. (1992). The new improved chart. Vol. 14 No 10, 9-11.

Latham G.P., \& Ernst, T. C. (2006). Keys to motivating tomorrow's workforce (Versi electronic). Journal of Human Resource Management, vol. 16 No 2, 181-198.

Lexy J. Moleong. (2002). Metode penelitian kualitatif. Bandung: PT Remaja Rosdakarya.

Lioyd. B.L. (2000). Management, skills and application. Boston, Georgia: McGraw - Hill Companies, Inc.

LunenBurg F.C., \& Ornstein, A.C. (2000). Educational administration: concept and practice. Stamford: Wardword Thomson Learning.

McNamara, C. (3 Juli 2007). General benefits of training and development. Di ambil pada tanggal 25 Mei 2007, dari http://www.manajementhelp. org/trng_dev/basics/reasons.htm\#anchor1287840

Miles \& Huberman. (1994). Qualitative data analysis, (2 ${ }^{\text {nd }}$ ed). Jakarta: Universitas Indonesia Press.

Minichiello, V., Aroni, R., Time well, E., et al. (1995). In depth interviewing, principles, techniques, analysis ( $2^{\text {nd }} \mathrm{ed}$.). Melbourne: Longman.

Mondy, R.W., Noe, R. M., Premeaux, S.R., (1999). Human resource management. $\left(7^{\text {th }} \mathrm{ed}\right)$. London: Prentice Hall International.

Naning Mardiah (2003). Hak atas pendidikan, bahan training monitoring hak ekonomi, sosial dan budaya. Jakarta: LP3ES.

Noe, R. M. ( 2005). Employee training and development ( $3^{\text {rd }}$ ed). Singapore: Mc Graw Hill, Inc.

Rudy C. Tarumingkeng. (14 February 2000). Peran strategis manajemen sumber daya manusia. Diambil pada tanggal 25 Mei 2007, dari http:// www.tumoutou.net/STRAT_PSDM.htm

Sanusi Uwes ( 1999). Manajemen pengembangan mutu dosen. Jakarta: Logos Wacana Ilmu.

Schuler, R. S., \& Jackson, S.E. (1999). Manajemen sumber daya manusia menghadapi abad 21. Jakarta: Erlangga. 
Siagian, S. P. (2003). Management sumber daya manusia. Jakarta: Sinar Grafika offset.

Sjafri Mangku Prawira (2001). Managemen sumber daya manusia strategis. Jakarta: PT Salemba Empat.

Soekijo Notoatmojo (1998). Pengembangan sumber daya manusia, edisi revisi, Jakarta: Reinika Cipta.

Stoner, J.A. F. \& Daniel. (1996). Management, (Terj.Sindoro). Jakarta: PT Prenhalindo.

Sudjana (2004). Manajemen program pendidikan untuk pendidikan nonformal dan pengembangan sumber daya manusia. Bandung: Falah Production.

Sugiyono (2006). Metode penelitian kuantitatif, kualitatif, dan $R \& D$. Bandung: Alfabetta.

Supardi \& Syaiful Anwar (2002). Dasar-dasar perilaku organisasi. Yogyakarta: UII Pers.

Sutrisno Hadi (2000). Metode research II. Yogyakarta: Andi Offset.

Suyanto \& MS Abas (2001). Wajah dan dinamika pendidikan anak bangsa. Yogyakarta: Adicipta Karya Nusa.

Walker, J. W. (1980). Human resource planning. New York. McGraw Hill Book Company.

Wanzare, Z.O (2002). Rethinking teacher evaluation in the third world. Journal of Educational management and administration, Vol. 30 No. 2, 213-215.

Wikipedia (18 Maret 2006) Manajemen sumber daya manusia. Di ambil pada tanggal 3 Mei 2007 dari http://id.wikipedia.org/wiki/Manajemen sumber_daya_daya_manusia 